Article

\title{
Efficient Control of Apple Scab with Targeted Spray Applications
}

\author{
Michael Chatzidimopoulos ${ }^{1, *(1)}$, Fenia Lioliopoulou ${ }^{1}$, Thomas Sotiropoulos ${ }^{2}$ and \\ Evangelos Vellios ${ }^{1}$ \\ 1 Department of Agriculture, Crop Production and Rural Environment, University of Thessaly, \\ 38446 N. Ionia, Volos, Greece; flioliop@uth.gr (F.L.); evellios@uth.gr (E.V.) \\ 2 Department of Deciduous Fruit Trees, Institute of Plant Breeding and Genetic Resources, \\ Hellenic Agricultural Organization 'Demeter', R.R. Station 38, 59035 Naoussa, Greece; thosotir@otenet.gr \\ * Correspondence: mxatzid@agr.uth.gr; Tel.: +30-6972-718-926
}

Received: 25 November 2019; Accepted: 27 January 2020; Published: 3 February 2020

\begin{abstract}
For two consecutive growing seasons (2017 and 2018), three different fungicide spray programs, each with five sprays from unrelated chemical groups, were evaluated for their effectiveness against apple scab (causal agent: Venturia inaequalis) in an experimental trial in Greece. The targeted application programs consisted of five sprays with protective and systemic fungicides from unrelated chemical groups, in alternation. The applications were started at the pink bud stage (a copper-based fungicide had previously been applied at the green bud stage) and completed at the second fruit fall to arrest the primary infections by ascospores. These five-spray programs were compared to the standard farmer practice (12 sprays per season), whereas untreated plots were used as controls. The timing of the applications was based: a) on the critical growth stage of the crop, and b) on the risk analysis for infection calculated by the software Field Climate, which incorporated meteorological data from the trial site. All the five-spray programs were of very high efficacy against apple scab, showing disease severity ratings on leaves and fruits below $1.88 \%$. In both years, in the untreated control, the disease incidence and severity on leaves ranged from $96.5 \%$ to $99.3 \%$ and from $65.2 \%$ to $75.93 \%$, respectively. The five-spray programs showed similar efficacy to the standard 12 -application program in all cases. From the results, it becomes apparent that apple scab can be controlled effectively by five targeted applications with selected fungicides at critical growth stages of the crop.
\end{abstract}

Keywords: Venturia inaequalis; disease control; fungicides; apple scab

\section{Introduction}

Apple scab, caused by Venturia inaequalis (Cooke) G. Wint., is the most important apple disease, causing economic losses in many apple production areas. The disease is more severe in regions like the Mediterranean in which frequent rainfall during spring results in ascospore release and infection [1]. Many scab control programs in the United States, Canada and Australia are aiming to protect trees against primary infections through repeated application of fungicides [2-4]. Due to the polycyclic nature of the disease, more than 12 fungicide treatments may take place each season to control apple scab [5]. However, with the high level of public concern about the possible side effects of pesticides on health and the environment, such practices have become less acceptable [6]. Certain disease control strategies have shown that the number of treatments could be reduced to seven applications per season using systemic fungicides when there is an increased infection risk [7]. However, these practices are outdated and no longer recommended due to resistance developed by the pathogen [1].

Current trends in agriculture demand the reduction of fungicide use to the minimal level needed for disease control, whilst more emphasis is given to alternative pathogen control strategies with 
products that induce resistance [8]. Modern integrated disease control strategies with a combination of fungicides and systemic resistance-inducing products may be useful in the management of apple scab. Furthermore, several simulation models based on Mills' periods [9] can serve as decision support systems for effective targeted applications against primary infections by calculating the duration of leaf wetness and ascospore maturation $[6,10]$.

The application of fungicides remains the primary tool to achieve superior control against apple scab. Spray programs may include protectant fungicides with multisite activity, which affect primarily spore germination, such as dithianon (quinone class), captan (phthalimide class) and Bordeaux mixture (copper-based), or systemic fungicides, which are absorbed by the plant and affect fungal growth, such as dodine (guanidine class), difenoconazole (demethylation inhibitor group; DMIs), pyraclostrobin (quinone-outside inhibitors; QoIs) and the anilinopyrimidine cyprodinil [11]. However, among all fungicides used against apple scab, a complete loss of efficacy in practice has been observed only in the case of the QoIs [12-14]. A recent survey in major apple growing areas in Greece, including the area of the trial site, revealed for the first time the occurrence of $V$. inaequalis strains with differential multi-drug resistance to the fungicides pyraclostrobin, dodine, difenoconazole, boscalid and cyprodinil [15].

Certain markets, including an increasing number of supermarket chains, demand a product with limited pesticide residues. In Greece, the standard practice against apple scab includes a minimum of 12 applications with 5-8 day intervals because the producers adopt a zero-tolerance policy towards apple scab on fruit [8]. To reduce the number of applications, weather-based forecasting systems may assist growers to control apple scab more efficiently by predicting the infection risk periods. However, only a few take into account the critical growth stages of the crop [6]. Furthermore, many growers are still relying on DMI and QoI classes of systemic fungicides despite the occurrence of practical resistance in the field after many years of use $[4,16]$. Therefore, the present work was undertaken: (i) to assess the efficacy and timing of different spray programs with optimum use of fungicides at key phenological stages of the crop, and (ii) to evaluate the effectiveness of targeted spray applications compared to the standard farmer practice against apple scab. In the present assay, the potential to control apple scab by applying a limited number of fungicides at key stages of the crop is investigated. The decision on the exact timing of applications is supported by a simulation model.

\section{Materials and Methods}

\subsection{Experimental Design}

The two-year trial (2017 and 2018) was performed in an apple orchard (cv. Pink Lady) located at the Department of Deciduous Fruit Trees Experimental Site, Department of Deciduous Fruit Trees, Institute of Plant Breeding and Genetic Resources, Greece (40.62 N, 22.12 E). The site was selected because there were outbreaks of the disease every year.

The trees were planted in 2010 and trained under the tall spindle system to an average height of $3.2 \mathrm{~m}$. The soil was a sandy loam containing $3.2 \%$ organic matter with a $\mathrm{pH}$ of 7.1 . Weeds were controlled mechanically using a mower. The trees were not irrigated nor fertilized during the two-year trial. A minimal insecticide program based on the insecticides spirotetramat (Movento Gold 100 SC, Bayer) and chlorantraniliprole (Coragen 20 SC, DuPont) was applied once in mid-May. Air temperature $\left({ }^{\circ} \mathrm{C}\right)$, leaf wetness duration (hours), and rainfall (millimeters) were recorded hourly by an electronic weather station (iMETOS IMT 300; Pessl Instruments) located at the edge of the orchard, linked to the cloud-based software Field Climate (build 0.13) for disease risk prediction.

The trials were organized in a randomized complete block design with four replications, according to the European and Mediterranean Plant Protection Organization's (EPPO) methods [17]. Each plot consisted of 5 trees, spaced $1.5 \mathrm{~m}$ apart, within rows that were $3 \mathrm{~m}$ apart. 


\subsection{Fungicide Programs}

Three different programs of fungicide sprays with protectant and systemic fungicides (Programs $1-3$, Table 1) were applied at key phenological stages of the crop [18]. These reduced-spray programs were compared to a program of conventional applications of fungicides simulating the standard farmer practice (Program 4, extensive applications) and an untreated control (sprayed with water). The interval between treatments for Program 4 and the untreated control (water sprays) was 5-8 days. All sprays were applied with a motorized backpack sprayer (SP 126, Oleo-Mac) equipped with an adjustable nozzle (S0112000R) with diameter $1.4 \mathrm{~mm}$ at $1000 \mathrm{~L} \mathrm{ha}^{-1}$ by thoroughly wetting the trees. To minimize the effects of neighboring treatments, the assessments were performed on the three central trees of each plot. At the green bud stage (BBCH 56), Bordeaux mixture (Cuprofix disperss 20 WG; UPL) was applied on all treated plots.

Table 1. Spray schedule for the control of apple scab at different phenological stages of the crop (cv. Pink lady).

\begin{tabular}{|c|c|c|c|c|}
\hline \multirow{2}{*}{$\begin{array}{c}\text { Phenological Growth } \\
\text { Stage (BBCH Scale) }\end{array}$} & \multicolumn{4}{|c|}{ Programs } \\
\hline & P1 & P2 & P3 & $\mathbf{P 4}$ \\
\hline Pink bud (57) & Dithianon $^{1}$ & $\begin{array}{l}\text { Dithianon+ } \\
\text { Potassium } \\
\text { phosphonate }\end{array}$ & Dodine & Dithianon \\
\hline First flowers open (60) & - & - & - & Dithianon \\
\hline Flowers $20 \%$ open $(62)$ & - & - & - & Dodine \\
\hline Full flowering (65) & Cyprodinil & $\begin{array}{l}\text { Cyprodinil+ } \\
\text { fludioxonil }\end{array}$ & Cyprodinil & Dithianon \\
\hline Flowers fading (67) & - & - & - & Captan \\
\hline End of flowering (69) & $\begin{array}{l}\text { Dithianon+ } \\
\text { Potassium } \\
\text { phosphonate }\end{array}$ & Dodine & $\begin{array}{l}\text { Dithianon+ } \\
\text { Potassium } \\
\text { phosphonate }\end{array}$ & Cyprodinil \\
\hline Fruit size 10 mm (71) & - & - & - & Mancozeb \\
\hline Fruit size 20 mm (72) & Captan & Captan & Captan & Trifloxystrobin \\
\hline Fruit size 20 mm (72) & - & - & - & Mancozeb \\
\hline Second fruit fall (73) & Difenoconazole & Difenoconazole & Difenoconazole & Difenoconazole \\
\hline Fruit $50 \%$ final size (75) & - & - & - & Mancozeb \\
\hline Fruit $50 \%$ final size (76) & - & - & - & $\begin{array}{l}\text { Tebuconazole+ } \\
\text { Trifloxystrobin }\end{array}$ \\
\hline $\begin{array}{l}{ }^{1} \text { The fungicide form } \\
\text { (BASF) at } 750 \mathrm{~g} / \text { ha; di } \\
\text { as Chorus } 50 \mathrm{WG} \text { (Syr } \\
\text { dodine as Syllit } 544 \text { SC } \\
25 \mathrm{EC} \text { (Syngenta) at } 30 \\
\text { Flint Max 75WG (Bay }\end{array}$ & $\begin{array}{l}\text { ns used and the st } \\
\text { on+potassium ph } \\
\text { a) at } 50 \mathrm{~g} / 100 \mathrm{~L} \text {; flu } \\
\text { sta) at } 1250 \mathrm{~mL} / \mathrm{ha} \\
\text { //ha; mancozeb as } \\
20 \mathrm{~g} / 100 \mathrm{~L} \text {. }\end{array}$ & $\begin{array}{l}\text { recommended r } \\
\text { late as Delan Pro } \\
\text { il+cyprodinil as } \\
\text { as Merpan } 80 \mathrm{~W} \\
\text { hoc } 72 \text { WP (UPL) }\end{array}$ & $\begin{array}{l}\text { applied were: dith } \\
56.1 \text { SC (BASF) at } 2 \\
\text { h } 25 / 37.5 \mathrm{WG} \text { (Syn } \\
\text { pha) at } 2000 \mathrm{~g} / \mathrm{ha} \text {; } \\
\mathrm{g} / 100 \mathrm{~L} \text {; tebuconaz }\end{array}$ & $\begin{array}{l}\text { as Delan } 70 \text { WG } \\
\mathrm{L} / \text { ha; cyprodinil } \\
\text { at } 100 \mathrm{~mL} / 100 \mathrm{~L} ; \\
\text { onazole as Score } \\
\text { rifloxystrobin as }\end{array}$ \\
\hline
\end{tabular}

\subsection{Decision Criteria for Fungicide Use}

The decision of the exact time for applications was supported by Field Climate software. The intervals between sprays for Programs 1-3 were determined at 7-12 days, commencing at the pink bud stage and based on the following criteria: (i) if good weather and no risk of infections were expected (Figure 1), the applications were delayed until the 12th day of the interval; (ii) if rain was expected or there was an increased risk of infections, the applications were performed earlier (before the rain event) and within the interval of 7-12 days; (iii) the sprays were targeted at critical growth stages (such as petal fall, Table 1) to cover the early spring growth. 
a

$\square$ Leaf wetness (h) $\quad$ Rain (mm) - Temperature $\left({ }^{\circ} \mathrm{C}\right)$

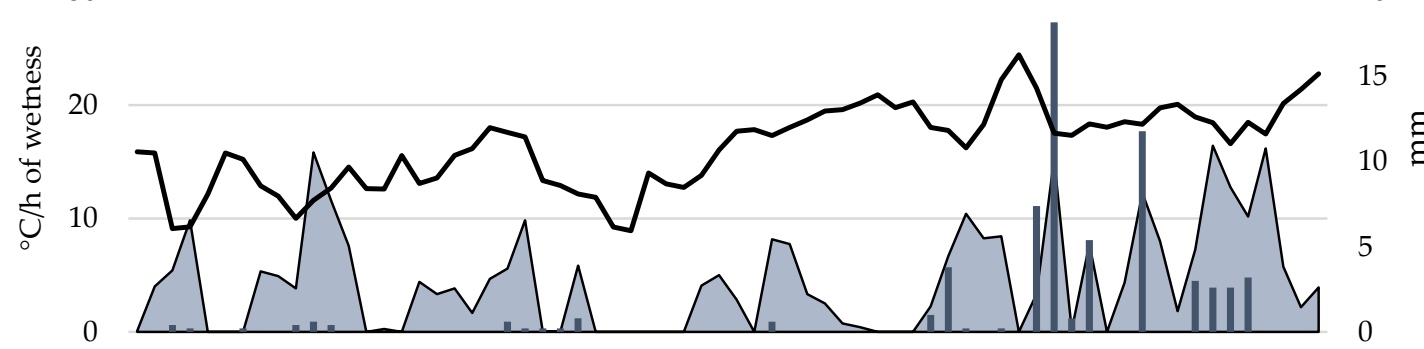

b
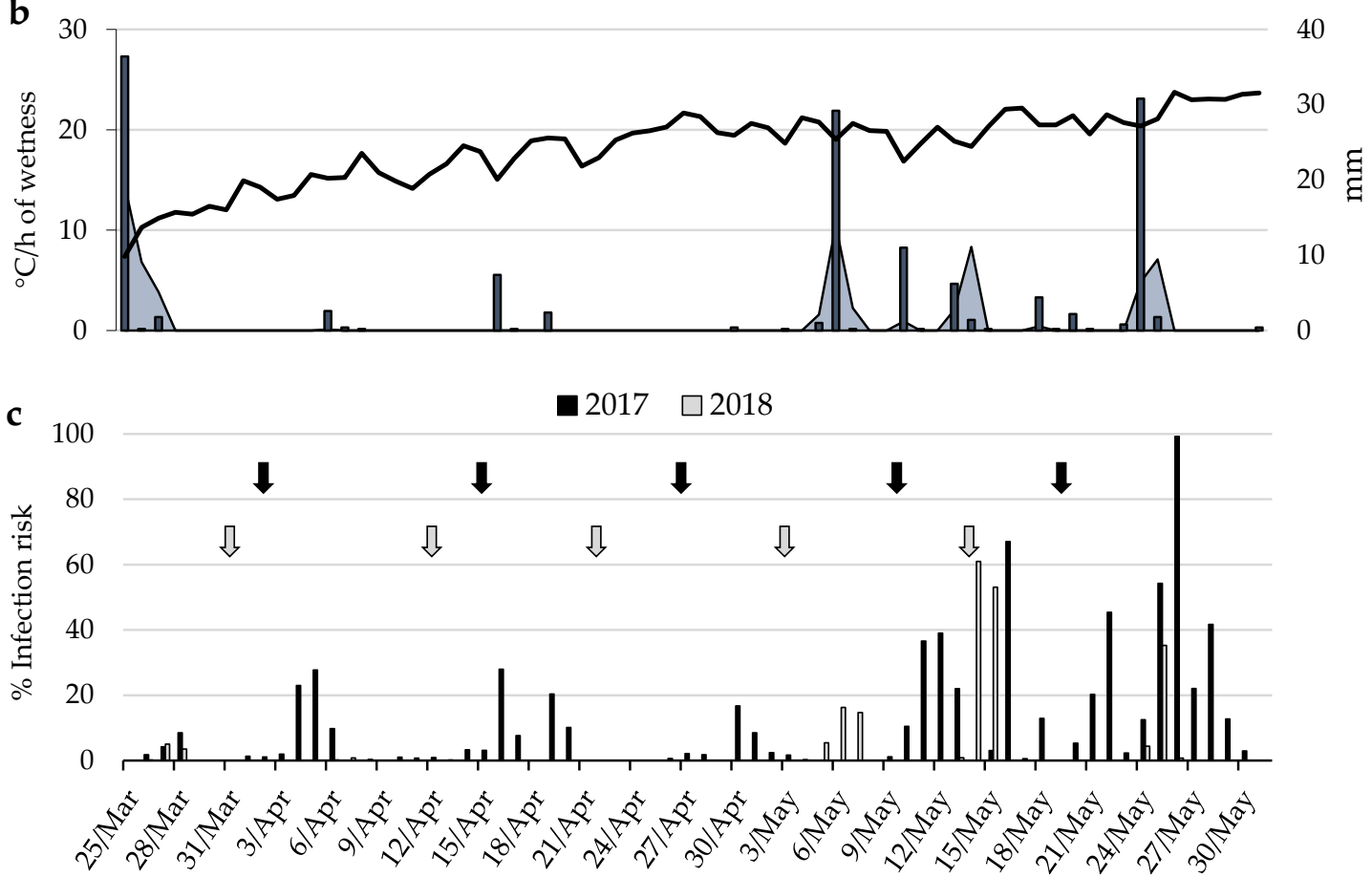

Figure 1. Weather data and infection risk analysis: (a) daily weather data in the 2017 trial; (b) daily weather data in the 2018 trial; (c) risk analysis for each infection period (2017 and 2018) and timing of five targeted applications commencing at the pink bud stage.

\subsection{Disease Incidence and Severity on Leaves and Fruits}

The disease incidence and severity were recorded every three weeks by counting the number of infected leaves on young shoots and rosettes and visually estimating their percentage diseased area. The sample size comprised of 200 leaves per plot according to EPPO methods [17]. At the last assessment in mid-June, the area under the scab progress curve (AUSPC) was calculated based on the formula:

$$
\text { AUSPC }=\sum_{i=1}^{N_{i}-1}\left(\frac{y_{i}+y_{i+1}}{2}\right)\left(t_{i+1}-t_{i}\right)
$$

where $t$ is the time of each assessment; $y$ is the percent disease severity at each assessment, and $n$ is the number of assessments.

The disease severity (S) on 100 fruits was evaluated using the Townsend-Heuberger's formula [19]:

$$
S(\%)=\frac{\sum\left(n_{i} v_{i}\right)}{N V} 100
$$


where $n$ is the degree of infection according to the scale: $0=$ no attack, $1=1-3$ spots per fruit, $2=>3$ spots per fruit; $v$ is the number of fruits per category; $V$ is the total number of fruits screened, and $N$ is the highest degree of infection.

The final assessment of disease incidence and severity on leaves and fruits was made four weeks after the last fungicide application. Four assessments were made in total.

\subsection{Statistical Analysis}

Data were analyzed by ANOVA and Tukey's honestly significant difference (HSD) test. To meet the assumptions of ANOVA, percentage and count values were logarithmically transformed to base 10 . $p$-values $\leq 0.05$ were considered significant. Statistical analysis and calculation of AUSPC values were carried out with ARM software (Revision 15958, Gylling Data Management, Brookings, SD, USA).

\section{Results}

\subsection{Disease Progress}

During the experimental periods in 2017 and 2018, environmental factors were favorable for the development of infections with average daily temperatures ranging from 8.9 to $24.4^{\circ} \mathrm{C}$ and from 7.4 to $23.7^{\circ} \mathrm{C}$, respectively (Figure 1a,b). The first symptoms appeared in the first week of April, prior to flowering. In the spring of 2017, the prolonged leaf wetness favored leaf infections and disease progress (Figure 2), as indicated by the increased infection risk in April and May according to Field Climate (Figure 1a,c and Figure 2). The 2018 experimental period was drier, but several rain events in May increased the risk of infections (Figure 1b,c). Apple scab infections were recorded on untreated trees in both the 2017 and 2018 trials as indicated by scab severity ratings of 75.93 and 65.2 on leaves, respectively (Figure 2). The respective AUSPC values in untreated controls were 3007.6 and 2630.8 (Table 2). The severe infections in untreated plots resulted in severe defoliation of the trees in late summer. On fruits, there was little difference in the degree of scab severity between the $2017(95.5 \%)$ and 2018 (92.63\%) growing seasons (Table 2). All fruits were severely infected (score of 2 on the scale) by apple scab.

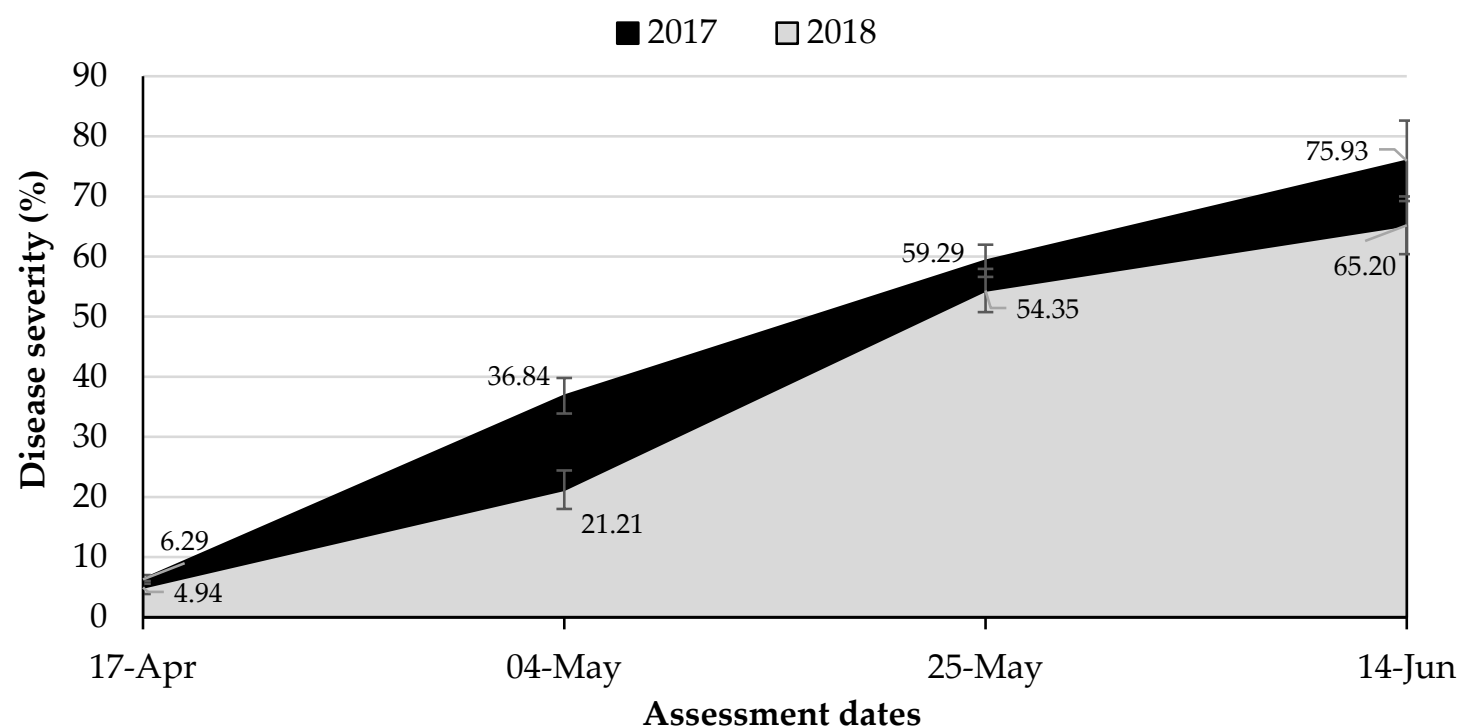

Figure 2. Disease progress in untreated control trees for two consecutive growing seasons. The disease severity on leaves over time was used for the calculation of the area under the scab progress curve (AUSPC). Bars represent the standard error (SE) of means. 
Table 2. Effects of different fungicide spray programs on scab incidence, severity and area under the scab progress curve ${ }^{1}$.

\begin{tabular}{|c|c|c|c|c|c|c|c|c|}
\hline \multirow{3}{*}{ Programs } & \multicolumn{8}{|c|}{ Year } \\
\hline & \multicolumn{4}{|c|}{2017} & \multicolumn{4}{|c|}{2018} \\
\hline & \multicolumn{2}{|c|}{ Leaves } & \multicolumn{2}{|r|}{ Fruits } & \multicolumn{2}{|c|}{ Leaves } & \multicolumn{2}{|r|}{ Fruits } \\
\hline P1 & $2.8^{3} \pm 0.5 b^{4}$ & $1.23 \pm 0.22 b$ & $48.67 \pm 1.52 b$ & $1.88 \pm 0.75 b$ & $1.5 \pm 0.3 b$ & $0.74 \pm 0.09 b$ & $36.72 \pm 2.82 b$ & $1.5 \pm 0.54 b$ \\
\hline P2 & $2.3 \pm 0.4 b$ & $1.34 \pm 0.27 b$ & $44.87 \pm 7.76 b$ & $1.75 \pm 0.63 b$ & $1.3 \pm 0.5 b$ & $0.92 \pm 0.13 b$ & $37.09 \pm 4.42 b$ & $0.88 \pm 0.43 b$ \\
\hline P4 & $0.8 \pm 0.5 b$ & $1.03 \pm 0.21 b$ & $33.95 \pm 5.76 b$ & $0.77 \pm 0.48 b$ & $0.5 \pm 0.3 b$ & $0.63 \pm 0.09 b$ & $27.65 \pm 5.39 b$ & $0.25 \pm 0.25 b$ \\
\hline Control & $99.3 \pm 0.5 a$ & $75.93 \pm 6.7 a$ & $3007.6 \pm 150.27 a$ & $95.5 \pm 2.62 \mathrm{a}$ & $96.5 \pm 1.8 \mathrm{a}$ & $65.2 \pm 4.8 \mathrm{a}$ & $2630.8 \pm 118.35 a$ & $92.63 \pm 3.13 a$ \\
\hline
\end{tabular}

${ }^{1}$ The data refer to the last assessment, which was made 4 weeks after the last application; ${ }^{2}$ the area under the scab progress curve consists of a quantitative summary of the disease severity on leaves; ${ }^{3}$ mean values including standard errors of means; ${ }^{4}$ means followed by the same letter do not significantly differ $(p \leq 0.05$, Tukey's honestly significant difference (HSD)).

\subsection{Evaluation of the Spray Programs}

All the reduced-spray programs provided excellent control of primary infections of scab. In both seasons, all the targeted spray programs were of very high efficacy, limiting the scab infections to very low levels. There were no significant differences in the control of the disease among the three different reduced-spray programs (Table 2). In the 2017 season, the disease incidence and severity on leaves ranged from $0.8 \%$ to $2.8 \%(p=0.1799)$ and from $1.03 \%$ to $1.34 \%(p=0.8125)$, respectively. In the 2018 season, the corresponding values ranged from $0.5 \%$ to $1.5 \%(p=0.4047)$ and from $0.63 \%$ to $0.92 \%(p=0.3029)$. The disease severity on fruits was also very low, ranging from $0.77 \%$ to $1.88 \%(p=0.1514-0.2628)$ in both seasons (Table 2). Compared to the standard farmer practice (P4), the reduced-spray programs showed similar efficacy. The AUSPC values of the treated plots were significantly lower compared to the untreated control $(p=0.0001)$, ranging from 33.95 to $48.67(p=0.4333)$ in the 2017 season and from 27.65 to 37.09 in the 2018 season $(p=0.4745)$, respectively (Table 2).

\section{Discussion}

In the present assay, it has been demonstrated that five fundamental applications with commonly used fungicides, at key phenological stages of the crop, were able to reduce apple infections to commercially acceptable levels. The value of the key-stage strategy and the danger of adopting a curative approach with the post-infection application of a systemic fungicide has been previously demonstrated [6]. To achieve maximum efficacy of the fungicides, treatments were aimed to control primary infections before the favorable conditions for infection occurred. One of the criteria for selecting the fungicides used in this study was the similarity to standard farmer practice. Protectant fungicides, such as dithianon and captan, were used either early in the season when there were only a few leaves present on the trees or when the infection risk generated by the simulation model was high [20]. Such applications, as employed in this study, protected the trees efficiently when the weather was dry (2018 season). One disadvantage of the protective fungicides is that they wash off from the leaf surface with just a few millimeters of rain. Recent studies have shown that captan and mancozeb can be washed off by as little as $1 \mathrm{~mm}$ of rain, although a certain proportion is likely to bind to the plant surface very tightly and hence may not be readily removed by rain [21,22]. In the 2017 season, approximately $40 \mathrm{~mm}$ of precipitation was recorded on May 15-18 after the application of captan. To efficiently protect the plants, an application with curative fungicide took place immediately after the rain events. The curative effect may last for 2-4 days with dodine, anilinopyrimidines and DMIs [23-25].

Dithianon, with its multisite activity, remains a valuable tool against apple scab, despite the fact that it has been used in practice for over 50 years [26]. Field experiments with new formulations of dithianon showed that up to $40 \mathrm{~mm}$ of rain are required to wash off the fungicide from the leaf surface [27]. Therefore, dithianon plays a major part in the development of control programs, especially 
in cases where rain events are expected. In some cases, it can be even applied shortly after light rain events as recent studies have shown that it has high activity $12 \mathrm{~h}$ after the beginning of scab infection [25]. Recently, it was formulated in a mixture with potassium phosphonates as Delan Pro to induce the plant's defense mechanisms against apple scab. In the present study, Delan Pro (P2) showed comparable efficacy to Delan (P1) when applied at the pink bud stage, despite the fact that it contained much less active ingredient (12.5\%). However, in order to enhance the defense mechanisms of the plants, the application should be repeated several times [8]. With this approach, Delan Pro can replace captan or other protectant fungicides in programs against apple scab.

Cyprodinil was selected to cover the sensitive stages of bloom to small fruitlet (10 mm size) in which rapid plant growth is observed [28]. Anilinopyrimidines, as systemic fungicides, are translocated in the apoplast of leaves, which results in the inhibition of later stages of pathogenesis, such as intercellular growth of the mycelium [29]. An anilinopyrimidine application on critical growth stages is highly recommended to protect the plant from additional infections (latent) with Botrytis and Monilia. Fludioxonil has recently been registered as a mixture with cyprodinil against apple scab and is a vital tool against fungicide resistance [30]. The mixture of fludioxonil plus cyprodinil in Program P2 provided similar disease control to cyprodinil when it was applied solo (Programs P1 and P3). Similarly, an application with the demethylation inhibitor difenoconazole was made in May, not just to prevent scab infections, but also because it additionally provides excellent control of powdery mildew-the next most important apple disease in Greece.

Dodine, as a local systemic fungicide, was selected to cover the sensitive stage of petal fall (P2) but it was also applied at the pink bud stage in Program P3. The combination of fungicides in Program P3 was found to be slightly more efficient than Programs P1 and P2. The inclusion of dodine in spray programs is important since there is a low risk of resistance development by $V$. inaequalis. Furthermore, the new formulation of dodine is not associated with fruit russeting, an issue commonly observed after applications with previous formulations of the fungicide [12]. The limitation of the use of the systemic fungicides cyprodinil, dodine and difenoconazole is highly recommended because of the resistance developed by the pathogen [16]. A recent survey in major apple growing areas in Greece, including the area of the trial site, revealed the occurrence of strains of $V$. inaequalis moderately resistant to the fungicides dodine, difenoconazole and cyprodinil, and highly resistant to QoIs [15]. However, our results demonstrate that those strains were efficiently controlled by the targeted spray programs when fungicides were applied at the full recommended rates.

Numerous simulation models, such as RIMpro and Adem, are currently available for assessing $V$. inaequalis primary infection risks [6,31]. The inclusion of a simulation model to assist in spray decisions enabled better timing of sprays in Programs P1, P2 and P3 compared to the standard farmer practice (P4), resulting in a similar scab control with fewer sprays despite the favorable weather for scab. This approach has shown that the fungicide use can be reduced by more than $50 \%$ compared to the typical farmer's program. The weather was drier in the 2018 period, but high disease severity ratings were recorded in control trees most probably because the site had a historical background of severe infections. In humid areas, the fruits should be inspected for late summer infections (pin-point scab), and if necessary extra spray applications should take place. It has been reported that certain sanitary practices such as leaf shredding, using urea fertilizer in autumn and summer pruning may contribute to scab control $[32,33]$. It is a common practice to remove the new plant growth during the apple thinning in the late spring-summer period, which is likely to be a source of inoculum. Furthermore, the spindle training system provides good aeration, which substantially decreases the leaf wetness period. Previous studies have shown that heavy pruning may reduce the apple scab progress on susceptible cultivars because it can alter the in-canopy microclimate and improve fungicide deposition [34].

\section{Conclusions}

It was shown that appropriate selection and timing of fungicide sprays is fundamental for apple scab control. Five targeted applications at key phenological stages of the crop were able to reduce 
scab infections to commercially acceptable levels. The limitation of the number of applications is in accordance with current trends in agriculture and may form the basis for a successful strategy against scab with additional sanitary practices.

Author Contributions: Conceptualization, M.C., F.L., T.S. and E.V.; methodology, M.C.; software, M.C. and T.S.; investigation, M.C., F.L., T.S. and E.V.; resources, M.C.; writing-original draft preparation, M.C.; writing-review and editing, M.C., F.L., T.S. and E.V.; supervision, E.V.; funding acquisition, M.C. All authors have read and agreed to the published version of the manuscript.

Funding: This research project was funded by the State Scholarships Foundation (I.K.Y.) under the Action 'Support of Postdoctoral Researchers' (MIS 5001552) in the framework of Operational Program 'Human Resources Development, Education and Lifelong Learning' with priority axes 6, 8, 9. It was co-funded by the European Social Fund and by National Resources through the National Strategic Reference Framework 2014-2020 (NSRF 2014-2020).

Conflicts of Interest: The authors declare no conflict of interest.

\section{References}

1. Bowen, J.K.; Mesarich, C.H.; Bus, V.G.M.; Beresford, R.M.; Plummer, K.M.; Templeton, M.D. Venturia inaequalis: The causal agent of apple scab. Molecular Plant Pathol. 2011, 12, 105-122. [CrossRef] [PubMed]

2. MacHardy, W.E.; Gadoury, D.M.; Gessler, C. Parasitic and biological fitness of Venturia inaequalis: Relationship to disease management strategies. Plant Dis. 2001, 85, 1036-1051. [CrossRef] [PubMed]

3. Beresford, R.M.; Manktelow, D.W.L. Economics of reducing fungicide use by weather-based disease forecasts for control of Venturia inaequalis in apples. New Zeal. J. Crop Hort. Sci. 1994, 22, 113-120. [CrossRef]

4. Jobin, T.; Carisse, O. Incidence of myclobutanil- and kresoxim-methyl-insensitive isolates of Venturia inaequalis in Quebec orchards. Plant Dis. 2007, 91, 1351-1358. [CrossRef]

5. Köller, W.; Wilcox, W.F. Evidence for the predisposition of fungicide-resistant Isolates of Venturia inaequalis to a preferential selection for resistance to other fungicides. Phytopathology 2001, 91, 776-781. [CrossRef]

6. Berrie, A.M.; Xu, X.M. Managing apple scab (Venturia inaequalis) and powdery mildew (Podosphaera leucotricha) using Adem ${ }^{\mathrm{TM}}$. Int. J. Pest Manag. 2003, 49, 243-249. [CrossRef]

7. Kunz, S.; Mögel, G.; Hinze, M.; Volk, F. Control of apple scab by curative applications of biocontrol agents. In Proceedings of the 13th international conference on cultivation technique and phytopathological problems in organic fruit-growing and viticulture, Weinsberg, Germany, 18-20 February 2008; pp. 62-67.

8. Percival, G.C.; Noviss, K.; Haynes, I. Field evaluation of systemic inducing resistance chemicals at different growth stages for the control of apple (Venturia inaequalis) and pear (Venturia pirina) scab. Crop Prot. 2009, 28, 629-633. [CrossRef]

9. Mills, W.D.; Laplante, A.A. Diseases and insects in the orchard. Cor. Uni. Ext. Bull. 1951, 711, $21-27$.

10. Beresford, R.M.; Henshall, W.R.; Palmer, J.W. A new apple scab risk model that integrates ascospore release, infection risk and susceptible leaf area. New Zeal. Plant Prot. 2004, 57, 20-24. [CrossRef]

11. Carisse, O.; Jobin, T. Apple scab: Improving Understanding for Better Management; Agriculture and Agri-Food Canada: Ottawa, Canada, 2006; Vol. 10203E, p. 22.

12. Mondino, P.; Casanova, L.; Celio, A.; Bentancur, O.; Leoni, C.; Alaniz, S. Sensitivity of Venturia inaequalis to trifloxystrobin and difenoconazole in Uruguay. J. Phytopathol. 2015, 163, 1-10. [CrossRef]

13. Fontaine, S.; Remuson, F.; Fraissinet-Tachet, L.; Micoud, A.; Marmeisse, R.; Melayah, D. Monitoring of Venturia inaequalis harbouring the QoI resistance G143A mutation in French orchards as revealed by PCR assays. Pest Manag. Sci. 2009, 65, 74-81. [CrossRef] [PubMed]

14. Lesniak, K.; Proffer, T.; Beckerman, J.; Sundin, G. Occurrence of QoI resistance and detection of the G143A mutation in Michigan populations of Venturia inaequalis. Plant Dis. 2011, 95, 927-934. [CrossRef] [PubMed]

15. Chatzidimopoulos, M.; Lioliopoulou, F.; Vellios, E.K. Characterization and distribution of fungicide resistant Venturia inaequalis phenotypes in Greece. In Proceedings of the 19th Hellenic Phytopathological Congress, Athens, Greece, 30 October-1 November 2018; p. 160.

16. Chapman, K.S.; Sundin, G.W.; Beckerman, J.L. Identification of resistance to multiple fungicides in field populations of Venturia inaequalis. Plant Dis. 2011, 95, 921-926. [CrossRef] [PubMed]

17. EPPO. Efficacy evaluation of fungicides. In Venturia Inaequalis and V. pirina; 2012; Vol. PP1/5(3), pp. $15-18$.

18. Meier, U. Growth stages of mono- and dicotyledonous plants; Julius Kühn-Institut: Quedlinburg, Germany, 2018. 
19. Townsend, G.R.; Heuberger, J.W. Methods for estimating losses caused by diseases in fungicidal experiments. Plant Dis. Reporter 1943, 27, 340-343.

20. Stević, M.; Vukša, P.; Elezović, I. Resistance of Venturia inaequalis to demethylation inhibiting (DMI) fungicides. Žemdirbystè-Agric. 2010, 97, 65-72.

21. Hunsche, M.; Damerow, L.; Schmitz-Eiberger, M.; Noga, G. Mancozeb wash-off from apple seedlings by simulated rainfall as affected by drying time of fungicide deposit and rain characteristics. Crop Prot. 2007, 26, 768-774. [CrossRef]

22. Xu, X.-M.; Murray, R.A.; Salazar, J.D.; Hyder, K. The effects of temperature, humidity and rainfall on captan decline on apple leaves and fruit in controlled environment conditions. Pest Manag. Sci. 2008, 64, $296-307$. [CrossRef]

23. Dahmen, H.; Staub, T. Protective, curative, and eradicant activity of difenoconazole against Venturia inaequalis, Cercospora arachidicola, and Alternaria solani. Plant Dis. 1992, 76, 774-777. [CrossRef]

24. Knauf-Beiter, G.; Dahmen, H.; Heye, U.; Staub, T. Activity of cyprodinil: Optimal treatment timing and site of action. Plant Dis. 1995, 79, 1098-1103. [CrossRef]

25. Battistini, G.; Finestrelli, A.; Brunelli, A.; Fiaccadori, R. Evaluation of curative activity of old and recent fungicides on Venturia inaequalis. In Proceedings of the Giornate Fitopatologiche, Bologna, Italy, 8-11 March 2016; pp. 345-351.

26. Huf, A.; Rehfus, A.; Teichmann, M.; Randall Gold, R.; Stammler, G. Sensitivity of Venturia inaequalis to fungicides. In Proceedings of the 18th International Reinhardsbrunn Symposium: Modern fungicides and antifungal compounds VIII, Friedrichroda, Germany, 24-28 April 2016; pp. 197-198.

27. Klitsinaris, T.; BASF Hellas S.A, Athens, Greece. Personal communication, 2019.

28. Schwabe, W.F.S.; Jones, A.L.; Jonker, J.P. Changes in the susceptibility of developing apple fruit to Venturia inaequalis. Phytopathology 1984, 74, 118-121. [CrossRef]

29. Krämer, W.; Schirmer, U.; Jeschke, P.; Witschel, M. Modern Crop Protection Compounds, 2nd ed.; Wiley-VCH: Weinheim, Germany, 2012; p. 1498.

30. Kilani, J.; Fillinger, S. Phenylpyrroles: 30 Years, Two Molecules and (Nearly) No Resistance. Front. Microbiol. 2016, 7. [CrossRef] [PubMed]

31. Trapman, M.; Polfliet, M. Management of primary infections of apple scab with the simulation program RIMpro: Review of four years field trials. IOBC-WPRS Bull. 1997, 20, 241-250.

32. Holb, I.J. Classification of apple cultivar reactions to scab in integrated and organic production systems. Can. J. Plant Pathol. 2007, 29, 251-260. [CrossRef]

33. Cooley, D.R.; Autio, W.R. Summer pruning of apple: Impacts on disease management. Adv. Hort. Sci. 2011, 25, 199-204.

34. Holb, I.J. Effect of pruning on apple scab in organic apple production. Plant Dis. 2005, 89, 611-618. [CrossRef] 